LETTER

\title{
Geochemical and Os isotopic characteristics of a fresh harzburgite in the Hayachine-Miyamori ophiolite: Evidence for melting under influx of carbonate-rich silicate melt in an infant arc environment
}

\author{
Masako YoshiKawA ${ }^{*}$, Katsuhiko SuzUkI ${ }^{* *}$, Tomoyuki SHIBATA ${ }^{*}$ and Kazuhito OzaWA ${ }^{* * *}$ \\ *Institute for Geothermal Sciences, Kyoto University, Beppu 874-0903, Japan \\ ${ }^{* *}$ Institute for Research on Earth Evolution, Japan Agency for Marine-Earth \\ Science and Technology, Yokosuka 237-0061, Japan \\ ${ }^{* * *}$ Department of Earth and Planetary Science, \\ The University of Tokyo, Tokyo 113-0033, Japan
}

\begin{abstract}
Os isotopic composition $\left({ }^{187} \mathrm{Os} /{ }^{188} \mathrm{Os}=0.1235\right)$ of a refractory harzburgite in the Hayachine-Miyamori ophiolite is subchondritic, indicating the long-term depletion of Re. Such an unradiogenic Os isotopic signature is consistent with the less oxidized condition at subduction initiation. The major and trace element characteristics of the harzburgite, together with its petrography and relatively high modal abundance of clinopyroxene, suggest an involvement of a carbonate-rich silicate melt during melt extraction in arc setting.
\end{abstract}

Keywords: Mantle wedge, Os isotopic composition, the Hayachine-Miyamori ophiolitic complex, Influx of carbonated-rich silicate melt

\section{INTRODUCTION}

The Hayachine-Miyamori (HM) ophiolitic complex in northeast Japan is suggested to have formed by open-system melting rather than metasomatism after partial melting on the basis of systematic changes of geochemical and modal compositions, and occurrence of primary amphiboles even in highly residual harzburgite (e.g., Ozawa, 1988; Ozawa and Shimizu, 1995). The chondrite-normalized trace element variation examined with open-system melting models (Ozawa, 2001) suggests that three distinct influx agents, which originated from various slab-derived components, were involved in the partial melting (Yoshikawa and Ozawa, 2007). The major and trace element compositions of whole rock peridotite provide direct information on magmatic processes in the upper mantle, such as partial melting, melt extraction, and refertilization. However, the original whole rock compositions of major and incompatible elements are susceptible to lowtemperature processes, such as serpentinization, to various extents (e.g., Gruau et al., 1998; Niu, 2004). We doi:10.2465/jmps.120624

M. Yoshikawa, masako@bep.vgs.kyoto-u.ac.jp Corresponding author found a fresh and large $(60 \mathrm{~cm}$ across $)$ boulder of harzburgite from the Miyamori complex, which may resolve the issue of low-temperature modification. We determined whole rock major and trace element compositions of the sample to scrutinize its geochemical nature of influx agents. We also obtained Re-Os isotopic data to discuss contribution of Os in influx agents from subducting slab, because the Os isotopic ratio $\left({ }^{187} \mathrm{Os} /{ }^{188} \mathrm{Os}\right)$ of oceanic lithosphere is much higher than residual depleted mantle left after simple partial melting and is believed to be a sensitive tracer for subducting slab-derived components (e.g., Brandon et al., 1996).

\section{PETROLOGICAL BACKGROUNDS AND SAMPLE}

The HM ophiolitic complex in the Kitakami Mountains, northeastern Japan, is located in the Hayachine Tectonic Belt, which is one of the oldest geological terrains in Japan (e.g., Ozawa, 1984; Ehiro, 2000; Fig. 1). The HM complex consists of ultramafic tectonite and cumulate members, which are structurally and chemically similar to the lower peridotite sections of ophiolites (e.g., Ozawa, 1984, Fig. 1). Peridotites in this complex are extensively 


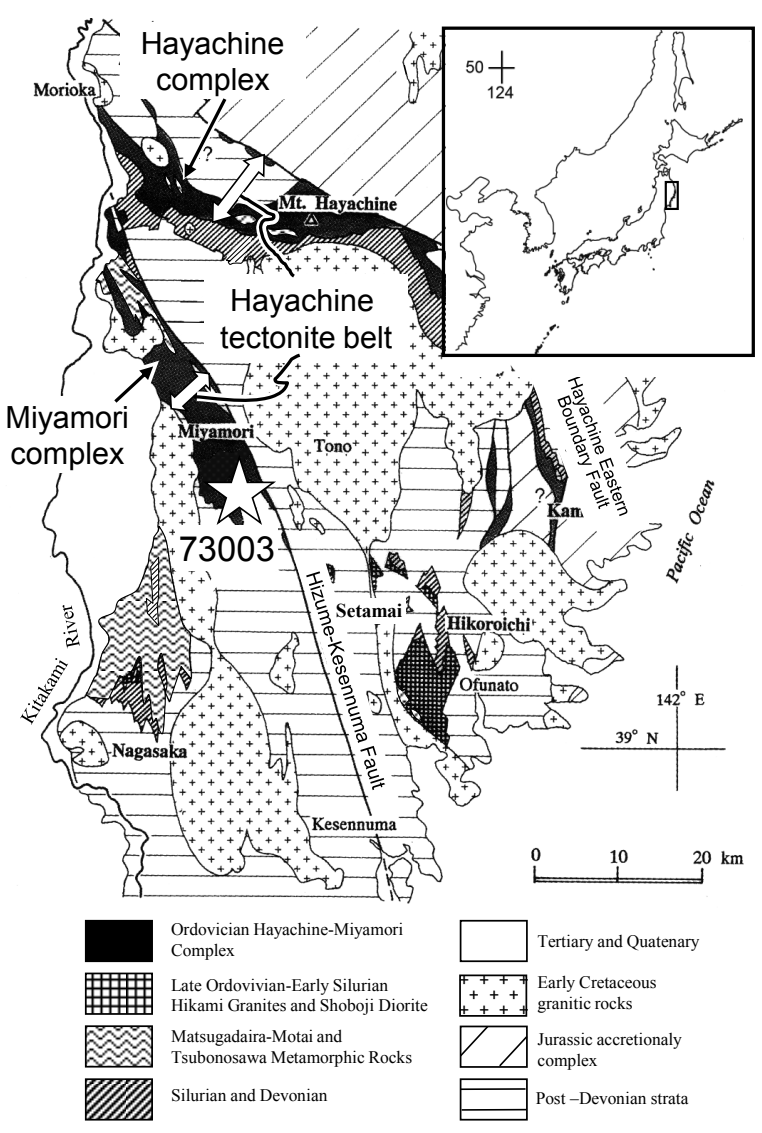

Figure 1. Geologic map of the HM ophiolitic complex (e.g., Ozawa, 1984; Yoshikawa and Ozawa, 2007). Open star denote sampling location.

serpentinized (mostly containing $>60$ vol $\%$ serpentine; Ozawa, 1988). The tectonite members are divided into two suites on the basis of spinel $\mathrm{Cr}$-number [Cr\# $=100 \times$ $\mathrm{Cr} /(\mathrm{Cr}+\mathrm{Al})]$ : aluminous spinel ultramafic suite (ASUS; $\mathrm{Cr} \#<40$ ) and chromite-bearing ultramafic suite (CSUS; Cr\# >40; Ozawa, 1988). The ASUS occurs as kilometerscale patches in the CSUS in the Miyamori complex and is widely distributed in the Hayachine complex (e.g., Ozawa, 1988). A peculiar feature of the refractory harzburgite in the HM complex is the presence of primary amphibole, indicating influx of a hydrous agent (Ozawa, 1988). A fresh harzburgite boulder (73003; $60 \mathrm{~cm}$ across) was found within the CSUS area of the Miyamori complex between the Sarugaishi and Otomo Rivers, approximately $1 \mathrm{~km}$ from the Hizume-Kesennuma Fault (Ozawa, 1988). This occurrence and petrographic and mineralogical features, such as spinel Cr\# ( 45), suggest that it belongs to the CSUS of the Miyamori complex (Fig. 1). The harzburgite sample shows a texture intermediate between tabular equigranular and porphyroclastic. Clinopyroxene shows a peculiar morphology with smooth concavity and locally exhibits cuspate outline (Fig. 2). Amphibole tends to be euhedral, aligning parallel to the foliation defined by spinel aggregates. Orthopyroxene is partly altered into aggregate of tremolite and diopside, which is further replaced by serpentine as described by Ozawa (1988).

\section{RESULTS}

The whole rock compositions of major and incompatible trace elements, and the ${ }^{187} \mathrm{Os} /{ }^{188} \mathrm{Os}$ isotopic ratio and concentration of Re and Os were determined for the 73003 (Table 1). The major element compositions of the sample 73003 are plotted in the field of the Horoman orogenic lherzolite complex in $\mathrm{MgO}$ variation diagrams, excepting in the $\mathrm{MgO}-\mathrm{CaO}$ and $\mathrm{MgO}-\mathrm{Al}_{2} \mathrm{O}_{3}$ plots (Fig. 3). This sample is characterized by higher $\mathrm{CaO} / \mathrm{Al}_{2} \mathrm{O}_{3}(\sim 2.3)$ ratio than the Horoman orogenic peridotites ( $\sim 1$; Fig 3$)$. Chondrite-normalized values of the whole rock trace element concentrations are plotted in Figure 4 with those of amphibole and clinopyroxene. They show extensive light rare earth element (LREE) and large ionic lithophile element enrichment (e.g., $\mathrm{La}_{\mathrm{N}} / \mathrm{Yb}_{\mathrm{N}}=9$ ) with depletion of high field strength element such as $\mathrm{Nb}, \mathrm{Zr}$, and $\mathrm{Hf}$ relative to the REE concentration (Fig. 4). The ${ }^{187} \mathrm{Os} /{ }^{188} \mathrm{Os}$ ratio $(0.1235)$ is lower than the present-day chondritic ratio (0.1270; Shirey and Walker, 1998). The value is within the range of the depleted mid-ocean ridge source mantle (DMM; $0.1247 \pm 0.0014$; Snow and Reisberg, 1995) and the Ichinomegata xenoliths from the Northeastern Japan arc (0.1206-0.1329; Brandon et al., 1996). The concentrations of $\operatorname{Re}(0.07497 \mathrm{ppb})$ and $\mathrm{Os}(1.301 \mathrm{ppb})$ are also within the range of the Ichimomegata xenoliths $(\mathrm{Re}=$ 0.0093 to $0.1082 \mathrm{ppb}, \mathrm{Os}=0.123$ to $2.080 \mathrm{ppb}$; Brandon et al., 1996).

\section{DISCUSSION AND CONCLURIONS}

Whole rock compositions acquired in high-temperature magmatic processes, particularly those of incompatible elements, are generally susceptible to low-temperature processes such as serpentinization, as compared with those in clinopyroxene and other minerals (e.g., Gruau et al., 1998). The whole rock chondrite-normalized incompatible trace element pattern of 73003 is principally parallel to those of clinopyroxene and amphibole (Fig. 4). This suggests that the whole rock elemental composition of sample 73003 has not been perturbed by a secondary lowtemperature process, and the boulder preserves the primary geochemical signature.

The CSUS harzburgites show higher $\mathrm{Cr} \#$, indicating higher degree of melting than the ASUS harzburgite. In the case of simple partial melting, clinopyroxene in residual peridotite decreases with increase in degree of melting 
Table 1. Major and trace element compositions of amphibole and whole rock of the sample 73003.

\begin{tabular}{|c|c|c|}
\hline & Whole rock & Amphibole \\
\hline \multicolumn{3}{|l|}{$w t \%$} \\
\hline $\mathrm{SiO}_{2}$ & 43.54 & 47.27 \\
\hline $\mathrm{TiO}_{2}$ & 0.02 & 0.11 \\
\hline $\mathrm{Al}_{2} \mathrm{O}_{3}$ & 0.95 & 9.86 \\
\hline $\mathrm{FeO}^{*}$ & 7.71 & 3.33 \\
\hline $\mathrm{MnO}$ & 0.13 & 0.04 \\
\hline $\mathrm{MgO}$ & 44.42 & 21.34 \\
\hline $\mathrm{CaO}$ & 2.17 & 11.15 \\
\hline $\mathrm{Na}_{2} \mathrm{O}$ & 0.00 & 1.72 \\
\hline $\mathrm{K}_{2} \mathrm{O}$ & 0.08 & 0.44 \\
\hline $\mathrm{Cr}_{2} \mathrm{O}_{3}$ & & 1.66 \\
\hline $\mathrm{NiO}$ & & 0.12 \\
\hline $\mathrm{Cr}(\mathrm{ppm})$ & 2950 & \\
\hline Ni (ppm) & 2256 & \\
\hline Totoal & 99.53 & 97.04 \\
\hline \multicolumn{3}{|l|}{ ppm } \\
\hline $\mathrm{Ti}$ & & 1081 \\
\hline $\mathrm{Rb}$ & 1.14 & 3.28 \\
\hline $\mathrm{Sr}$ & 13.5 & 364 \\
\hline $\mathrm{Y}$ & 0.386 & 9.89 \\
\hline $\mathrm{Zr}$ & 1.49 & 38.6 \\
\hline $\mathrm{Nb}$ & 0.05 & 1.15 \\
\hline Cs & 0.12 & \\
\hline $\mathrm{Ba}$ & 5.48 & 190 \\
\hline $\mathrm{La}$ & 0.34 & 10.8 \\
\hline $\mathrm{Ce}$ & 1.00 & 35.6 \\
\hline $\operatorname{Pr}$ & 0.16 & 5.80 \\
\hline $\mathrm{Nd}$ & 0.80 & 31.3 \\
\hline $\mathrm{Sm}$ & 0.194 & 7.42 \\
\hline $\mathrm{Eu}$ & 0.0581 & 2.34 \\
\hline Gd & 0.167 & 4.70 \\
\hline $\mathrm{Tb}$ & 0.0198 & 0.56 \\
\hline Dy & 0.0879 & 2.14 \\
\hline Ho & 0.0145 & 0.35 \\
\hline Er & 0.0389 & 0.83 \\
\hline $\mathrm{Tm}$ & 0.0052 & 0.10 \\
\hline $\mathrm{Yb}$ & 0.0374 & 0.82 \\
\hline $\mathrm{Lu}$ & 0.0064 & 0.11 \\
\hline $\mathrm{Hf}$ & 0.0379 & 0.82 \\
\hline $\mathrm{Ta}$ & & 0.08 \\
\hline $\mathrm{Pb}$ & 0.0271 & 0.30 \\
\hline Th & 0.0197 & 0.31 \\
\hline $\mathrm{U}$ & 0.0075 & 0.09 \\
\hline \multicolumn{3}{|l|}{ ppb } \\
\hline $\mathrm{Re}$ & 0.0750 & \\
\hline Os & 1.301 & \\
\hline${ }^{187} \mathrm{Os} /{ }^{188} \mathrm{Os}$ & 0.12349 & \\
\hline $2 \sigma$ & \pm 0.00028 & \\
\hline
\end{tabular}

Major elements of whole rock were determined by XRF RIGAKU System 3070. Trace elements were determined by ICP-MS Thermo-SCIENTIFIC X2. Total Fe shows as FeO. Major element compositions of amphibole are from Yoshikawa and Ozawa (2007). Re and Os concentrations and Os isotopic compositions were determined by ThermoSCIENTIFIC MAT262 thermal ionization mass spectrometry (Suzuki and Tatsumi, 2001).
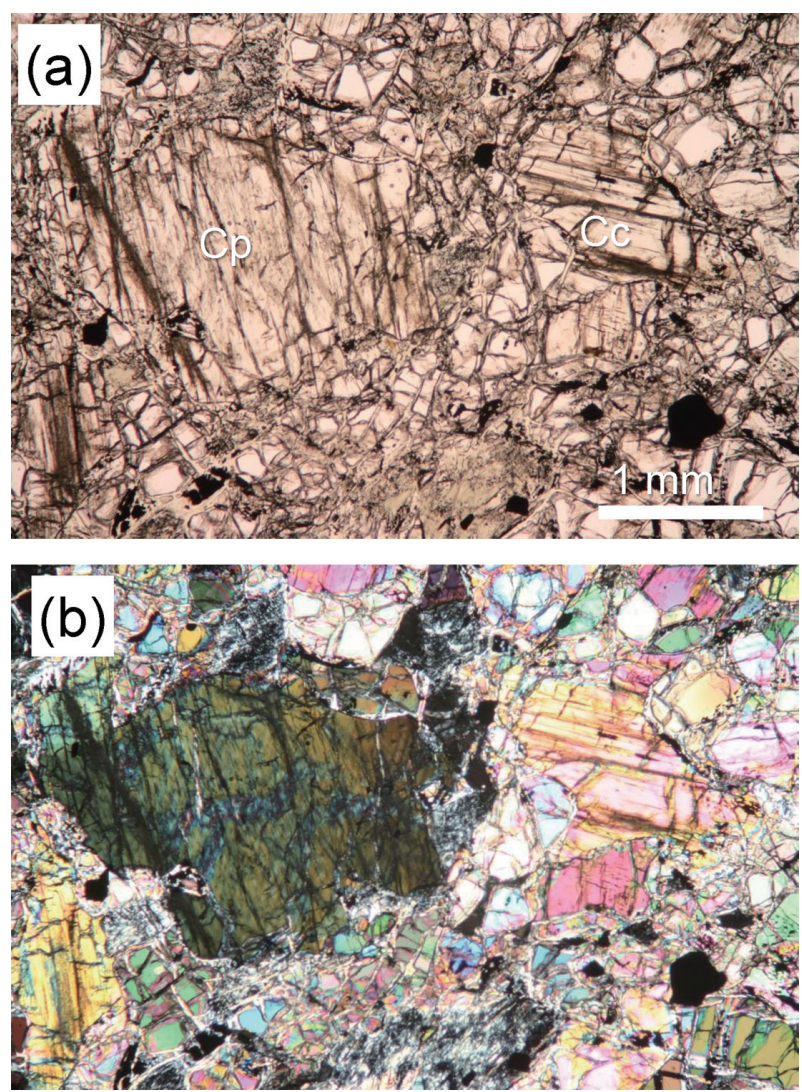

Figure 2. Photomicrograph of the 73003 harzburgite; (a) plane-polarized transmitted light and (b) cross-polarized transmitted light. Clinopyroxene has a morphology characterized by concavity to a various extent. The grain on the left hand side $(\mathrm{Cp})$ has an outline weakly curved and concave to the contacting olivine. The clinopyroxene on the right hand side $(\mathrm{Cc})$ has a shape with remarkable concavity, which can be called cuspate.

and melt extraction. The modal abundances of clinopyroxene in the 73003 and other CSUS harzburgites, however, are as high $(\leq 3.7 \mathrm{vol} \%)$ as those in the ASUS harzburgite ( $\leq 4.3$ vol\%; Ozawa and Shimizu, 1995; Fig. 5). This implies addition of a clinopyroxene component to the CSUS harzburgites during melting. Similarly high abundance of clinopyroxene in peridotites that underwent a high degree of melting was observed in the Puy Beaunit peridotite xenoliths, Massif Central, which is shown to have been metasomatized by carbonatite-silicate melt derived from subducted slab (Fig. 5; Yoshikawa et al., 2010). The low $\mathrm{Al}_{2} \mathrm{O}_{3}(\leq 2 \mathrm{wt} \%)$ and high $\mathrm{CaO}(\geq 24 \mathrm{wt} \%)$ contents of clinopyroxenes in the CSUS harzburgites including sample 73003 (Ozawa, 1988; Yoshikawa and Ozawa, 2007) are similar to those of clinopyroxenes of the Southeastern Australian xenoliths, for which an interaction of orthopyroxene and carbonatite melt is proposed as a plausible process (Yaxely et al., 1998). The unusually high $\mathrm{CaO} / \mathrm{Al}_{2} \mathrm{O}_{3}$ ratio $(>1)$ of peridotite is attributed to the precipitation of secondary clinopyroxene and/or apatite ow- 
ing to influx of Ca-rich agents. The involved agents may be either carbonatite melt (e.g., Yaxely et al., 1991) or carbonate-rich silicate melt (Laurora et al., 2001). This scenario can be adopted for the origin of the sample 73003 having high $\mathrm{CaO} / \mathrm{Al}_{2} \mathrm{O}_{3}$ ratio of $\sim 2.3$. The clinopy-
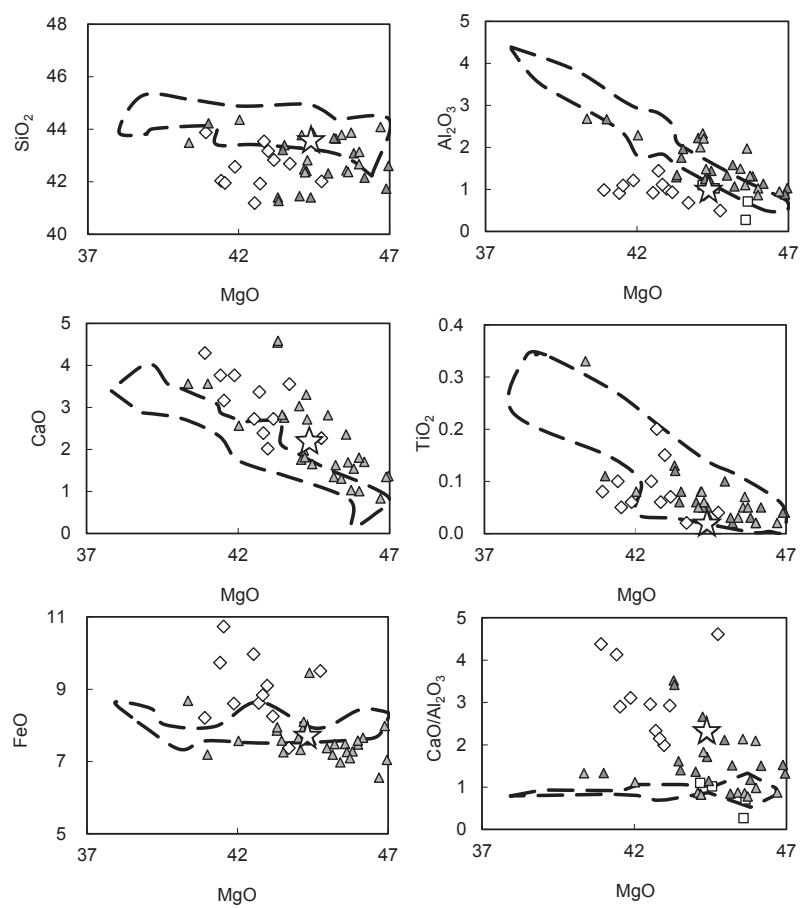

Figure 3. $\mathrm{MgO}-\mathrm{Oxide}(\mathrm{wt} \%)$ variation diagrams for whole rock. The broken lined area is as the fields of peridotites from the Horoman peridotite complex (Takazawa et al., 1992; Yoshikawa and Nakamura, 2000).

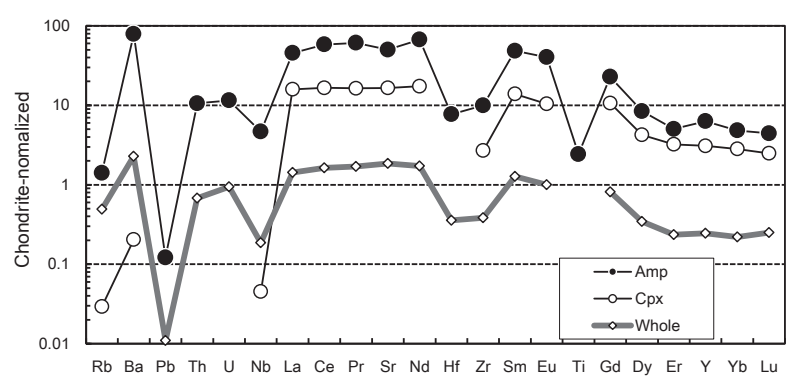

Figure 4. Chondrite-normalized trace element patterns of whole rock measured by a ThermoSCIENTIFIC X2 quadruple inductively coupled plasma mass spectrometry (Q-ICP-MS) housed at the Institute of Geothermal Sciences (I.G.S.) at Beppu, Kyoto University, Japan. The amphibole (Amp) was analyzed on thin polished slabs $(\sim 100 \mu \mathrm{m})$ using a $266 \mathrm{~nm}$ UV Nd YAG laser (CETAC LSX 200), connected to Q-ICP-MS. The pattern of clinopyroxene (Cpx) estimated by secondary ion mass spectrometry is also shown (Yoshikawa and Ozawa, 2007). Normalizing values are from Sun and McDonough (1989).

roxene morphology mentioned above suggests that the influx took place during the magmatic event.

The trace element composition of the melt, influxed
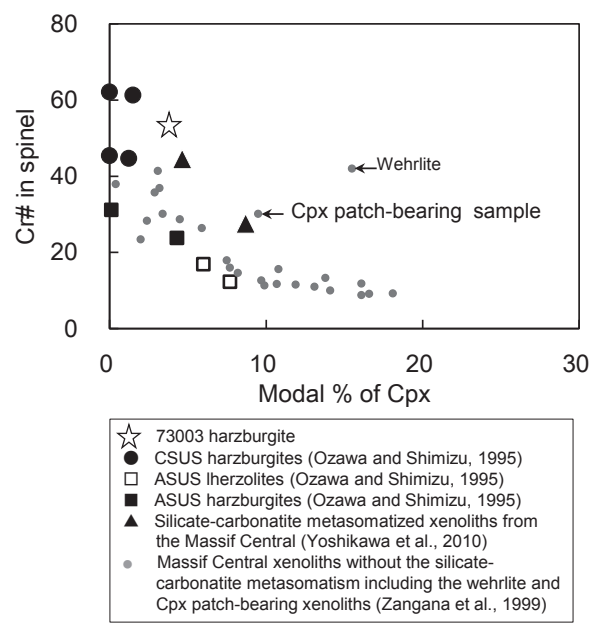

Figure 5. Modal abundances of clinopyroxene (Cpx) and $\mathrm{Cr} \#$ [100 $\times \mathrm{Cr} /(\mathrm{Cr}+\mathrm{Al})]$ of spinel.

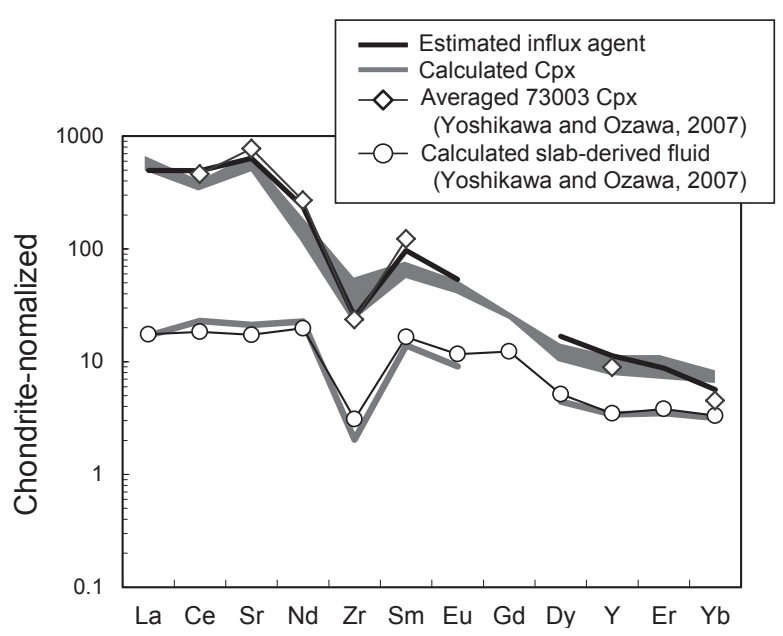

Figure 6. Trace element compositions of influxed agent involved in the CSUS peridotites, which were estimated by reproducing the averaged 73003 clinopyroxene composition (Yoshikawa and Ozawa, 2007) with an open-system melting model (Ozawa and Shimizu, 1995). In the open-system melting model, the system is open to both input (fluid/melt influx) and output (melt segregation) during partial melting processes, and is based on a general mass conservation balance equation in an open magmatic system formulated by Ozawa (2001). The bulk source composition was estimated from clinopyroxene composition in the most fertile Hayachine lherzolite, and the used initial mode, melting stoichiometry, and partition coefficients between melt and minerals were those of Ozawa and Shimizu (1995). The calculated clinopyroxene (Cpx) composition can be fitted by the model if melting degree of $15 \%$, mass influx rate of 0.7 , and trapped melt fraction of 0.02 are adopted. The range of the putative agent of Patagonia xenoliths (shaded area; Laurora et al., 2001) is also shown. 


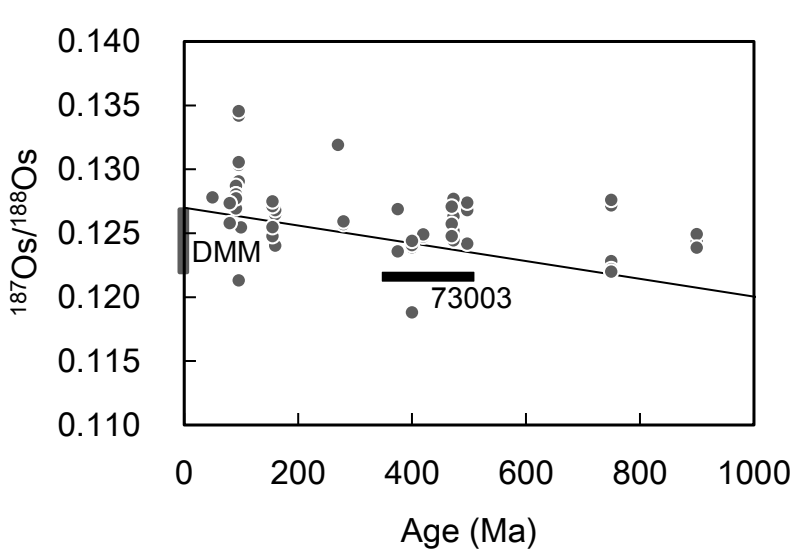

Figure 7. Calculated initial ${ }^{187} \mathrm{Os} /{ }^{186} \mathrm{Os}$ isotopic range of the 73003 harzburgite using previously obtained age (430-510 Ma; Shibata and Ozawa, 1992; Yoshikawa and Ozawa, 2007). The initial Os isotopic data for chromitites in ophiolites (Walker et al., 2002) and present depleted mid-ocean ridge source mantle (DMM) range (Snow and Reisberg, 1995) are also shown. Solid line is the evolution line for the chondrite (Shirey and Walker, 1998).

during the melting of 73003, was estimated by an opensystem melting model (Ozawa and Shimizu, 1995; Ozawa, 2001) by reproducing those of 73003 clinopyroxenes (Fig. 6). The calculated residual clinopyroxenes composition is also plotted in Figure 6 for comparison. The estimated melt shows LREE enrichment and positive anomaly of $\mathrm{Sr}$ and negative anomaly of $\mathrm{Zr}$, which suggest an involvement of a slab derived component (Yoshikawa and Ozawa, 2007). The trace element pattern is similar to that of the putative carbonate silicate agent of the Patagonia xenoliths, which occur in a back-arc tectonic setting in the Chile arc, and this influxed melt was most likely to be derived from subducting slab (Laurora et al., 2001; Fig. 6). We thus infer that the CSUS peridotites underwent influx of a carbonate-rich silicate melt in an arc setting.

The ${ }^{187} \mathrm{Os} /{ }^{188} \mathrm{Os}$ ratio $(0.1235 \pm 0.0004)$ is within the range of the DMM (0.1221-0.1270; Snow and Reisbrg, 1995), although $\mathrm{Sr}-\mathrm{Nd}$ isotopic and trace element signatures of the HM ophiolite clearly require an extensive influx of arc-related agent (Yoshikawa and Ozawa, 2007). The ${ }^{187} \mathrm{Os} /{ }^{188} \mathrm{Os}$ ratio is subchondritic, indicating a longterm depletion of Re and survival of the platinum group elements feature from melt influx enriched in incompatible elements. The HM complex has been interpreted to have been formed in the early Ordovician on the basis of the Sm-Nd crystallization age of gabbro $(510 \pm 70 \mathrm{Ma}$; Shibata and Ozawa, 1992), the Nd model age of the ASUS peridotites (430 Ma; Yoshikawa and Ozawa, 2007), and the $\mathrm{Sm}-\mathrm{Nd}$ isochron age employing the previously reported data of the ASUS lherzolites (Yoshikawa and Ozawa, 2007), which is $490 \pm 60$ Ma with initial ${ }^{143} \mathrm{Nd} /{ }^{144} \mathrm{Nd}=0.51230 \pm 0.00013$ (ISOPLOT, the open file report 91-445, Ludwig, 2003). Subchondritic Os isotopic composition of sample 73003 is consistent with melt depletion in the early Ordovician (around $500 \mathrm{Ma}$ ) suggested by previous studies.

We calculated the initial Os isotopic compositions with an assumption that partial melting occurred during 430-510 Ma. The results range from 0.12113 to 0.12150 and are lower than chondritic evolution line (Fig. 7). This initial Os isotopic variation is the lower end value of the initial Os isotopic compositions of the chromites from ophiolitic peridotites (Walker et al., 2002; Fig. 7). Walker et al. (2002) suggested that Os isotopic compositions of ophiolites formed in an arc setting did not largely modified by radiogenic melts or fluids derived from subducting slabs. The Os isotopic compositions of mantle wedge xenoliths from Ichinomegata were, however, significantly modified by slab contributions (Brandon et al., 1999). Recently, Suzuki et al. (2011) discovered the DMM-like Os isotopic composition of chromian spinels from boninite, and interpreted that the mantle beneath the Izu-Bonin arc was not strongly oxidized during boninite formation in the infant arc stage, because experimental work demonstrated that solubility of Os in fluid at low oxygen fugacity was an order of magnitude smaller than those of fluids at high oxygen fugacity (Xiong and Wood, 2000). The HM ophiolitic complex initially underwent back arc spreading and then arc magmatism following the initiation of subduction (Ozawa, 1988; Yoshikawa and Ozawa, 2007). Thus, we think that the Os isotopic composition of the CSUS peridotite has not been modified by influx of slab-derived carbonate-rich silicate melt because of less oxidized conditions in the incipient arc stage.

\section{ACKNOWLEDGMENTS}

The author thanks Dr. T. Morishita, an anonymous reviewer, and Dr. T. Kogiso of associate editor for critical and constructive reviews. This study was financially supported by a part of KAKENHI and the Kyoto University. M.Y. is grateful to Dr. K. Takemura and Ms. K. Yoshikawa for the encouragement during this study.

\section{REFERENCES}

Brandon, A.D., Creaser, R.A., Shirey, S.B. and Carlson, R.W. (1996) Osmium Recycling in Subduction Zones. Science, 272, 861-864.

Ehiro, M. (2000) Relationships in tectonic framework among the South Kitakami and Hayachine Tectonite Belts, Kurosegawa Belt, and "Paleo-Ryoke Belt". The Memories of the Geological Society of Japan, 56, 53-64.

Gruau, G., Griffiths, J.B. and Lecuyer, C. (1998) The origin of Ushaped rare earth patterns in ophiolite peridotites: Assessing 
the role of secondary alteration and melt/rock reaction. Geochimica et Cosmochimica Acta, 62, 3545-3560.

Laurora, A., Mzaaucchelli, M., Rivalenti, G., Vannucci, P., Zanetti, A., Barbieri, A. and Cingolani, C.A. (2001) Metasomatism and melting in carbonated peridotite xenoliths from the mantle wedge: The Gobernador Gregores Case (Southern Patagonia). Journal of Petrology, 42, 69-87.

Ludwig, K.R. (2003) ISOPLOT 3.00: A Geochronological Toolkit for Microsoft Excel, Berkeley Geochronology Center Special Publication, Berkeley, California.

Niu, Y. (2004) Bulk-rock major and trace element compositions of abyssal peridotites: implications for mantle melting, melt extraction and post-melting processes beneath mid-ocean ridges. Journal of Petrology, 45, 2423-2458.

Ozawa, K. (1984) Geology of the Miyamori ultramafic complex in the Kitakami mountains, Northeast Japan. Journal of the Geological Society of Japan, 90, 697-716.

Ozawa, K. (1988) Ultramafic tectonic of the Miyamori ophiolitic complex in the Kitakami Mountains, Northeast Japan: hydrous upper mantle in an island arc. Contributions to Mineralogy and Petrology, 99, 159-175.

Ozawa, K. (2001) Mass balance equations for open magmatic systems: trace element behavior and its application to open system melting in the upper mantle. Journal of Geophysical Research, 106, 13407-13434.

Ozawa, K. and Shimizu, N. (1995) Open-system melting in the upper mantle: Constraints from the Hayachine-Miyamori ophiolite, northeastern Japan. Journal of Geophysical Research, 100, 22315-22335.

Shirey, S.B. and Walker, R.J. (1998) The Re-Oe isotope system in cosmochemistry and high-temperature geochemistry. Annual Reviews of Earth and Planetary Science, 26, 423-500.

Shibata, K. and Ozawa, K. (1992) Ordovician arc ophiolite, the Hayachine and Miyamori complexes, Kitakami Mountains, northeast Japan: isotopic age and geochemistry. Geochemical Journal, 26, 85-97.

Snow, J.E. and Reisberg, L. (1995) Os isotopic systematics of the MORB mantle: results from altered abyssal peridotites. Earth and Planetary Science Letters, 133, 411-421.

Sun, S.-S. and McDonough, W.F. (1989) Chemical and isotopic systematics of oceanic basalts: implications for mantle composition and processes. In Magmatism in the Ocean Basins (Saunders, A.D. and Norry, M.J. Eds.). Geological Society Special Publication, 42, 313-345.

Suzuki, K. and Tatsumi, Y. (2001) Osmium concentrations and ${ }^{187} \mathrm{Os} /{ }^{188} \mathrm{Os}$ ratios of GSJ reference samples, JB-1a, JA-2 and JP-1. Geochemical Journal, 35, 207- 210.

Suzuki, K., Senda, R. and Shimizu, K. (2011) Osmium behavior in a subduction system elucidated from chromian spinel in Bonin Island beach sands. Geology, 39, 999-1002.

Takazawa, E., Frey, F.A., Shimizu, N., Obata, M. and Bodinier, J.L. (1992) Geochemical evidence for melt migration and reaction in the upper mantle. Nature, 359, 55-58.

Walker, R.J., Prichard, H.M., Ishiwatari, A. and Pimentel, M. (2002) The osmium isotopic composition of convecting upper mantle deduced from ophiolite chromites. Geochimica et Cosmochimica Acta, 66, 329-345.

Xiong, Y. and Wood, S.A. (2000) Experimental quantify cation of hydrothermal solubility of platinumgroup elements with special reference to porphyry copper environments. Mineralogy and Petrology, 68, 1-28.

Yaxley, G.M., Crawford, A.J. and Green, D.H. (1991) Evidence for carbonatite metasomatism in spinel peridotite xenoliths from western Victoria, Australia. Earth and Planetary Science Letters, 107, 305-317.

Yaxley, G.M., Green, D.H. and Kamenetsky, V. (1998) Carbonatite Metasomatism in the Southeastern Australian Lithosphere. Journal of Petrology, 39, 1917-1930.

Yoshikawa, M. and Nakamura, E. (2000) Geochemical evolution of the Horoman peridotite complex: Implications for melt extraction, metasomatism, and compositional layering in the mantle. Journal of Geophysical Research, 105, 2879-2901.

Yoshikawa, M. and Ozawa, K. (2007) Rb-Sr and Sm-Nd isotopic systematics of the Hayachine-Miyamori ophiolitic complex: Melt generation process in the mantle wedge beneath an Ordovician island arc. Gondowana Research, 11, 234-246.

Yoshikawa, M., Kawamoto, T., Shibata, T. and Yamamoto, J. (2010) Geochemical and $\mathrm{Sr}-\mathrm{Nd}$ isotopic characteristics and pressure-temperature estimates of mantle xenoliths from the French Massif Central: evidence for melting and multiple metasomatism by silicate-rich carbonatite and asthenospheric melts. In Petrological Evolution of the European Lithospheric Mantle (Coltorti, M., Downes, H., Gregoire, M. and O'Reilly, S.Y. Eds.). pp. 337, Geological Society, London, Special Publications.

Zangana, N.A., Downes, H., Thirlwall, M.F. and Hegner, E. (1997) Relationship between deformation, equilibration temperatures, REE and radiogenic isotopes in mantle xenoliths (Ray Pic, Massif Central, France): an example of plume-lithosphere interaction? Contributions to Mineralogy and Petrology, 127, 187-203.

Manuscript received June, 24, 2012

Manuscript accepted October 24, 2012

Published online December 1, 2012

Manuscript handled by Tetsu Kogiso 